\title{
Satisfaction from Academic Activities among Medical Students in Malaysia
}

\author{
Redhwan A. Al-Naggar ${ }^{*}$, Yuri V. Bobryshev ${ }^{2}$ \\ ${ }^{1}$ Population Health and Preventive Medicine Department, Faculty of Medicine, Universiti Teknologi \\ MARA (UiTM), Malaysia \\ ${ }^{2}$ Faculty of Medicine, School of Medical Sciences, University of New South Wales, New South Wales, \\ Sydney NSW2052, Australia. \\ *E-mail: redhwan4803@salam.uitm.edu.my, radhwan888@yahoo.com

\begin{abstract}
There is a lack of data about the levels of satisfaction among medical students in regards to their academic activities in Malaysia. Therefore, the objective of this study was to fill the gap in the existing knowledge. A cross sectional study was carried out at the International medical school, the Management and Science University of Malaysia, from December 2011 to February 2012. A total of 200 medical students were participated in this study through random sampling. The questionnaires used in this study consisted of socio-demographic questions and questions about the existing academic system. The study found that, despite there was the satisfaction by medical students from some academic aspects, improvements in other areas, such as providing digital library and career counseling, are urgently needed. The present study provides the world community with factual information about the current situation in medical education in Malaysia. The results of the study might assist Malaysian administrators and authorities in better decision making.
\end{abstract}

Key Words: medical students; academic activities; satisfaction

\section{Introduction}

Recently, there have been dramatic changes in medical education world-wide (Roff et al. 1997). The medical training in Asia is traditionally teacher centric and relies on hospital based training (Abeykoon and Mattock 1996). Continues evaluation system is essential to determine if the current system is working to produce a better product (Coles and Grant 1985). The relationship between the administrative structures of the medical school and the teaching hospitals, the other responsibilities of teachers and administrators, and the details of the curriculum as a system of inter related components means that any new change has wide repercussions (Grant and Gales 1989). Curriculum evaluation includes gathering information about the merits and demerits of the educational program.

Feedback from learners is an invaluable source for improving current medical education (Chessman et al. 1998, Distlehorst 2000). This monitoring helps to determine whether corrective measures are indicated (Bandaranayake 1989). Seeking feedback from student is a reasonable approach to evaluation of the medical schools' educational programme, and is commonly used in other parts of the world. In the United States, Graduate Exit Questionnaire (GEQ) is a part of the routine educational process. Medical graduates' evaluation of the educational program in GEQ is utilized for quality assurance and curriculum revision (Bandaranayake 1989). This monitoring helps to determine whether corrective measures are indicated (Bandaranayake 1989). There is a lack of data about satisfaction level among medical students in regards to their academic activities in Malaysia. Therefore, the objective of this study was to determine the satisfaction from academic activities among medical students. We hope 
that the results of this study will provide useful information about the MBBS curriculum and that the results of the present study would benefit administrators in better decision making.

\section{Methodology}

A cross sectional study was carried out at international school, Management and Science University from December 2011 to February 2012. A total number of 200 international medical students from phase 1 , phase 2 and phase 3 were participated in this study through random sampling. The study protocol was reviewed and approved by the ethics committee of Management and Science University and the study was carried out in accordance with the declaration of Helsinki of 1975 as revised in 1983. The questionnaires used in this study consist of socio-demographic characteristics such as gender, race, and age; another part was about the academic system in University. The students satisfaction rate was measured by a 5 point Likert type scale i.e., a- strongly agree, b- agree, c- disagree, d- strongly disagree, e-no idea. Therefore, the students in part B were required to rate it according to their satisfaction level. Lastly, there was only one opened ended question. Here, the students were given opportunity to express their suggestions, opinion and recommendations. The questionnaire was adopted from a study of Manzar and Manzar (2011). Non-medical students, nursing students were excluded from this study. The participants were explained about the purpose of the study, confidentiality was ensured and written consent was obtained. Data were entered in a Statistical Package for Social Sciences (SPSS version 13) and analysis of the data was done using frequencies. Descriptive analysis was used to assess the different variables in the study.

\section{Results}

A total number of 200 medical students were participated in this study. The mean age was 21.8 with minimum age 18 years old and maximum age 29 years old. The majority of the students were female, Malay, from phase one, from urban areas and used car as transportation to the university $(76.5 \%, 44 \%$, $53 \%, 82 \%, 42 \%$; respectively) (Table 1 ).

Table 1. Socio-demographic characteristics of the medical students $(n=200)$

\begin{tabular}{llcc}
\hline Variables & Categorize & Number & $\%$ \\
\hline Gender & Male & 47 & 23.5 \\
Race & Female & 153 & 76.5 \\
& Malay & 88 & 44 \\
& Indian & 79 & 39.5 \\
\multirow{5}{*}{ Phase } & Chinese & 19 & 9.5 \\
& Others & 14 & 7.0 \\
& I & 106 & 53 \\
Residency & II & 59 & 29 \\
\multirow{2}{*}{ Transportation used to university } & III & 35 & 17.5 \\
& Urban & 164 & 82 \\
& Rural & 36 & 18 \\
& Car & 84 & 42 \\
& Taxi & 12 & 6 \\
& Bus & 13 & 6.5 \\
& Train & 5 & 2.5 \\
& Walking & 71 & 35.5 \\
& Bicycle & 2 & 1 \\
& Motorcycle & 13 & 6.5 \\
\hline
\end{tabular}

(C) 2013, European Journal of Educational Research, 2(1), 17-24 
Regarding the participants view about curricular system, most of them strongly agreed and agreed that they were satisfied with the current method of teaching ( $21 \%, 75 \%$; respectively). In terms of interaction between students and lecturers during the classes, most of them strongly agreed $(19.5 \%)$ and agreed $(69 \%)$ that there is a good interaction between students and lecturers during the classes. The majority of the students strongly agreed (31\%) and agreed (63\%) that problem based learning should be applied on the learning process. Similarly most of them strongly agreed (37.5\%) and (57.5\%) that small group discussion gives better understanding regarding the subject (Table 2).

Table 2. Medical Students view regarding curricular system $(\mathrm{n}=200)$

\begin{tabular}{|c|c|c|c|c|c|}
\hline Question/Issue & $\begin{array}{l}\text { Strongly } \\
\text { agree } \\
\mathrm{N}(\%)\end{array}$ & $\begin{array}{l}\text { Agree } \\
\text { N (\%) }\end{array}$ & $\begin{array}{c}\text { Disagree } \\
\mathrm{N}(\%)\end{array}$ & $\begin{array}{c}\text { Strongly } \\
\text { disagree } \\
\mathrm{N}(\%)\end{array}$ & $\begin{array}{l}\text { No idea } \\
\text { N }(\%)\end{array}$ \\
\hline $\begin{array}{l}\text { Current method of } \\
\text { teaching is } \\
\text { satisfactory }\end{array}$ & $21(10.5 \%)$ & $150(75 \%)$ & $23(11.5 \%)$ & $3(1.5 \%)$ & $3(1.5 \%)$ \\
\hline $\begin{array}{l}\text { There is good interac- } \\
\text { tion between students } \\
\text { and lectures during } \\
\text { the classes }\end{array}$ & $39(19.5 \%)$ & $138(69.0 \%)$ & $20(10.0 \%)$ & $2(1.0 \%)$ & $1(0.5 \%)$ \\
\hline $\begin{array}{l}\text { The multiple mode of } \\
\text { assessment helps the } \\
\text { students to excel }\end{array}$ & $25(12.5 \%)$ & $141(70.5 \%)$ & $23(11.5 \%)$ & $6(3.0 \%)$ & $5(2.5 \%)$ \\
\hline $\begin{array}{l}\text { Lecture should } \\
\text { accompanied with } \\
\text { multimedia tool such } \\
\text { as animation and } \\
\text { video }\end{array}$ & $79(39.5 \%)$ & $112(56.0 \%)$ & $4(2.0 \%)$ & $3(1.5 \%)$ & $2(1.0 \%)$ \\
\hline $\begin{array}{l}\text { The university labora- } \\
\text { tory gives sufficient } \\
\text { lab materials for ex- } \\
\text { periments }\end{array}$ & $23(11.5 \%)$ & $109(54.5 \%)$ & $44(22.0 \%)$ & $19(9.5 \%)$ & $5(2.5 \%)$ \\
\hline $\begin{array}{l}\text { Problem based lear- } \\
\text { ning should be app- } \\
\text { lied on the learning } \\
\text { process }\end{array}$ & $62(31.0 \%)$ & $126(63.0 \%)$ & $7(3.5 \%)$ & $1(0.5 \%)$ & $4(2.0 \%)$ \\
\hline $\begin{array}{l}\text { Small group discussi- } \\
\text { on gives better un- } \\
\text { derstanding regarding } \\
\text { the subject }\end{array}$ & $75(37.5 \%)$ & $115(57.5 \%)$ & $6(3.0 \%)$ & $3(1.5 \%)$ & $1(0.5 \%)$ \\
\hline $\begin{array}{l}\text { Self-directed learning } \\
\text { is more helpful }\end{array}$ & $28(14.0 \%)$ & $92(46.0 \%)$ & $56(28.0 \%)$ & $17(8.5 \%)$ & $7(3.5 \%)$ \\
\hline $\begin{array}{l}\text { The viva system is } \\
\text { effectiveness }\end{array}$ & $29(14.5 \%)$ & $107(53.5 \%)$ & $32(16 \%)$ & $15(7.5 \%)$ & $17(8.5 \%)$ \\
\hline $\begin{array}{l}\text { There is academic } \\
\text { workload }\end{array}$ & $49(24.5 \%)$ & $108(54.0 \%)$ & $30(15.0 \%)$ & $2(1.0 \%)$ & $11(5.5 \%)$ \\
\hline $\begin{array}{l}\text { Satisfaction with the } \\
\text { phase system }\end{array}$ & $23(11.5 \%)$ & $126(63.0 \%)$ & $26(13.0 \%)$ & $11(5.5 \%)$ & $14(7.0 \%)$ \\
\hline
\end{tabular}


In terms of students suggestions to improve the academic activities, most of them strongly agreed $(20 \%)$ and agreed $(63.5 \%)$ that digital library will attract more students to use the information as part of their learning activities. Most of the students strongly agreed $(24 \%)$ and agreed $(60 \%)$ that career counseling help should be provided by the university. Moreover, the majority of the students strongly agreed and agreed $(19.5 \%, 47 \%$; respectively) that there is inadequate pre-clinical teaching (Table 3).

Table 3. Students suggestions for improvement in regards to academic activities $(n=200)$

\begin{tabular}{|c|c|c|c|c|c|}
\hline Question/Issue & $\begin{array}{c}\text { Strongly agree } \\
\text { N (\%) }\end{array}$ & $\begin{array}{l}\text { Agree } \\
\text { N (\%) }\end{array}$ & $\begin{array}{c}\text { Disagree } \\
\text { N }(\%)\end{array}$ & $\begin{array}{c}\text { Strongly } \\
\text { disagree } \\
\mathrm{N}(\%)\end{array}$ & $\begin{array}{c}\text { No idea } \\
\text { N }(\%)\end{array}$ \\
\hline $\begin{array}{l}\text { Digital library will } \\
\text { attract more students to } \\
\text { use the information as } \\
\text { part of their learning }\end{array}$ & $40(20 \%)$ & $127(63.5 \%)$ & $19(9.5 \%)$ & $4(2.0 \%)$ & $10(5.0 \%)$ \\
\hline $\begin{array}{l}\text { Career counseling help } \\
\text { should be provided by } \\
\text { the university }\end{array}$ & $48(24.0 \%)$ & $120(60.0 \%)$ & $19(9.5 \%)$ & $1(0.5 \%)$ & $12(6.0 \%)$ \\
\hline $\begin{array}{l}\text { There is inadequate } \\
\text { pre-clinical teaching }\end{array}$ & $39(19.5 \%)$ & $94(47.0 \%)$ & $40(20.0 \%)$ & $11(5.5 \%)$ & $16(8.0 \%)$ \\
\hline
\end{tabular}

Regarding the mode of assessment preferred by students (Table 4); they prefer mixed method assessment rather than one method. The most preferred assessment preferred was MCQ (33.5\%), MEQ (30\%), OSPE/OSCE (18.5\%) and the lowest was SEQ (18\%). Regarding the preferable time and duration of lectures, most of the students reported that morning classes $(90.5 \%)$ is the most preferable and one hour $(77 \%)$ is the ideal duration for lecture (Table 5 and 6 ).

Table 4. Assessment methods preferred by students $(n=200)$.

\begin{tabular}{lcccc}
\hline Which mode of assessment & $*$ MCQ & $*$ MEQ & *OSPE/OSCE & *SEQ \\
help the student to excel & $\mathrm{N}(\%)$ & $\mathrm{N}(\%)$ & $\mathrm{N}(\%)$ & $\mathrm{N}(\%)$ \\
\hline & $67(33.5 \%)$ & $60(30.0 \%)$ & $37(18.5 \%)$ & $36(18.0 \%)$ \\
\hline
\end{tabular}

*OSPE: Object Structured Practical Examination; OSCE: Object Structured Clinical Examination; MCQ: Multiple Choice Question. 
Table 5. Ideal time period for the classes preferred by students $(n=200)$

\begin{tabular}{lcccc}
\hline Which is the ideal time period & Morning & Afternoon & Evening & Night \\
for the classes? & $\mathrm{N}(\%)$ & $\mathrm{N}(\%)$ & $\mathrm{N}(\%)$ & $\mathrm{N}(\%)$ \\
\hline & $181(90.5 \%)$ & $9(4.5 \%)$ & $3(1.5 \%)$ & $7(3.5 \%)$ \\
\hline
\end{tabular}

Table 6. Ideal duration for the lectures preferred by students $(n=200)$

\begin{tabular}{lcc}
\hline How long should a lecture take place? & 1 hour & 2 hours \\
& $\mathrm{N}(\%)$ & $\mathrm{N}(\%)$ \\
\hline & $154(77.0 \%)$ & $46(23.0 \%)$ \\
\hline
\end{tabular}

\section{Discussion}

This study carried out to determine the major factors that adversely affect the curricular activities and satisfaction rate among medical students in a medical school, Malaysia. In this study, the majority of the students strongly agreed $(31.0 \%)$ and agreed $(63.0 \%)$ that problem based learning should be applied on the learning process. In this study also, respondents strongly agreed (37.5\%) and agreed (57.5\%) that small group discussion gives better understanding regarding the subject. Similar findings reported that respondents were of the view that Problem Based Learning (PBL) and small group discussions could be more helpful than didactic style of teaching (Rooney et al. 1999, Farida et al. 2006, Yawar and Shah 2003). In a recent study carried out by Nandi et al, they found that students of the newer problem-based learning curriculum found learning to be "more stimulating and more humane" whereas students of the conventional curriculum found learning to be "non relevant, passive, and boring" (Nandi et al. 2000). Similar results have been documented in studies carried out by Fischer et al (2004), and Costa et al (2007) where they found that interactive style of teaching and group discussions were more preferred by the undergraduate students than lecture based didactic learning.

In this study $10.5 \%$ of the students strongly agreed and $70 \%$ agreed with the current method of teaching. Similar studies were reported the satisfaction rate of $28.4 \%$ and $90.2 \%$ for Iran and USA respectively (Jalili et al. 2008; Association of American Medical Colleges 2006). In this study; the majority of the students agreed that lecture should be not more than hour (77\%). Many students found 30 minutes to be adequate for a lecture and were of the opinion that any teaching beyond the 30 minutes led to over saturation and excess information. Increased lecture time has also been cited in many studies for skipping lectures (Hashmi et al. 2010). In a survey conducted by Trevena (2003), it was noted that students felt that self directed learning in basic and clinical sciences was more effective than lectures.

In this study the majority of the students prefer MCQ (33.5\%) followed by MEQ (30\%), SEQ $(18 \%)$ and OSPE/OSCE (18.5\%). Similar findings have been revealed by Abraham et al (2005) where students suggested a need for multiple modes of assessment rather that single mode of assessment which in their view could not fulfill assessment of all aspects of student's knowledge effectively. In the view of the students introduction of the semester system enabled the students to focus better on their studies due to pressure of regular performance in exams. Students were also of the view that OSCE was 
the standard method of evaluating clinical skills today in a neutral environment as compared to the old viva voce pattern of examination which in their view was biased. Most of the students favored BCQ method of assessment as in their view it promoted critical thinking. In a study carried out by Oyebola et al (2000), students preference were slightly different with the majority of the participants in the study supporting MCQ based assessment.

The majority of the students strongly agreed (24.0\%) and agreed (60.0\%) that career counseling help should be provided by the university. Similar finding was reported by (Manzar and Manzar, 2011) that the respondents were also dissatisfied with the university for not conducting career planning and future guidance seminars for the students. Many students were confused in regards to their choice of future field of study and were of the view that their uncertainty could be resolved with proper counseling. However counseling and career planning is a rare phenomenon in developing countries of Asian origin where no such facility exists even at the university level. Despite the confusion regarding their future field of study most of the respondents were confident of their success in the years to come while others were more skeptical.

At the end of the questionnaire, students asked if they have any suggestion to improve the current situation. There three themes extracted from their suggestions: Academic improvement; facilities, management issues, lecturers and extracurricular activities. In terms of academic, most of the students suggested that the classes should start at 9.00 am or 10.00 am rather than 8.00 am and the total hours are not more than 8 hours class per day.

Another suggestion by most of them suggested reducing the Self-Directed Learning (SDL) session and increasing Problem Based Learning (PBL). Students also suggest that the teaching method should be improved for instance more videos and more small group discussion. This consistent with the qualitative part which 39.5\% strongly agreed and 56.0\% agreed that lecture should accompanied with multimedia tool such as animation and video.

Students suggested for more interactive way of learning, hands on training. Moreover, they need special session weekly for current medical issues. Similar findings have been noted by different studies worldwide (Trevena 2003, Bokken et al. 2009, Martens et al. 2009). In terms of management, some of the student suggested to improve the student attendance system and should be an electronic attendance. In terms of lecturers, they suggested more lecturers should be hired. Since most of medical schools in Malaysia run by foreign lecturers, some student find difficulties with the foreign lecturer's language or even, sometimes, with English slang. These students indicated that they would prefer to have more lectures to be provided by local lecturers. In terms of extracurricular activities, many of the students suggested that the outdoor activities should be expanded. Some of them indicated that mentoring activity should be done every week. A few students mentioned also that there should be regular visits in order to do community services.

\section{Limitation of the Study}

The study presents results from a public sector medical university and, therefore, limits a possibility of the generalization of the obtained data for private medical colleges where situation may be somehow different. Nonetheless, we believe that the present study holds important implications for policy makers helping to determining what future strategies and planning need to be undertaken to tackle student's problems and contentment with the curriculum.

\section{Acknowledgements}

We thank the International Medical School, Management and Science University, Malaysia, and the School of Medical Sciences, University of New South Wales, Sydney, Australia, for support. 


\section{References}

Abeykoon P, Mattock N(1996). Medical education in South-East Asia New Delhi: regional office for South-East Asia. Geneva; World Health Organ.

Abraham RR, Upadhya S, Torke S, Ramnarayan K (2005). Student perspectives of assessment by TEMM model in physiology. Adv Physiol Educ 29, 94-97.

Association of American Medical Colleges (2006). Graduation Questionnaire. Available from: https://www.aamc.org/download/90062/data/gq-2006.

Bandaranayake R(1989). Implementing change in medical education in developing countries. Med Teacher 11, 39-45.

Bokken L, Rethans JJ, van Heurn L, Duvivier R, Scherpbier A, van der VIeuten C (2009). Students' views on the use of real patients and simulated patients in undergraduate medical education. Acad Med 84, 958-963.

Chessman AW, Bellack JP, Lahoz MR, White AW, Kennedy B, Slaughter SC, Cleghorn GD (1998). Students add value to learning organizations: the Medical University of South Carolina experience. Qual Manag Health Care 6, 38-43.

Coles CR, Grant JG (1985). Curriculum evaluation in medical and health-care education. Med Educ 19, 405-442.

Costa ML, van Rensburg L, Rushton N (2007). Does teaching style matter? A randomised trial of group discussion versus lectures in orthopedic undergraduate teaching. Med Educ 41, 214-217.

Distlehorst LH (2000). What graduate follow-up studies can tell us. Med Educ 34, 976-977.

Farida H, Lubna B, Farah AM (2006) Opinion of medical students regarding problem based learning. $J$ Pak Med Assoc 56, 430-432.

Fischer RL, Jacobs SL, Herbert WNP (2004). Small-group discussion versus lecture format for thirdyear students in obstetrics and gynecology. Obstet Gynecol 104, 349-353.

Grant J, Gales R (1989) Changing medical education. Med Educ 2, 252-257.

Hashmi NR, Daud S, Manzoor I. (2010). Medical Education: Views and Recommendations by Final Year MBBS Students of a Private Medical College in Lahore. J Coll Physicians Surg Pak 20, 93-97.

Jalili M, Mirzazadeh A, Azarpira A (2008). A survey of medical students' perceptions of the quality of their medical education upon graduation. Ann Acad Med 37, 1012-1018.

Manzar B, Manzar N (2011). To determine the level of satisfaction among medical students of a public sector medical university regarding their academic activities. BMC Res Notes 4, 380.

Martens MJ, Duvivier RJ, van Dalen J, Verwijnen GM, Scherpbier AJ, van der Vleuten CP (2009). Student views on the effective teaching of physical examination skills: a qualitative study. Med Educ 43, 184-191.

Nandi PL, Chan JN, Chan CP, Chan P, Chan LP (2000).Undergraduate medical education: comparison of problem-based learning and conventional teaching. Hong Kong Med J 6, 301-306.

Oyebola DD, Adewoye OE, Iyaniwura JO, Alada AR, Fasanmade AA, Raji Y (2000). A comparative study of students' performance in preclinical physiology assessed by multiple choice and SEQs. Afr J Med Sci 29, 201-205.

Roff S, McAleer S, Harden R, Al-Qahtani M, Ahmed AU, Deza H, Groenen G, Primparyon P (1997). Development and validation of the Dundee Ready Education Environment Measure (DREEM). Med Teacher 19, 295-299.

Rooney S, Cullivan R, Kelly G (1999). Irish students and medical education. Irish J Med Sci 168:2715 .

Trevena L (2003) What medical student's value in a population health tutor: characteristics for consideration in staff recruitment and development. Educ Health 16, 51-58. 


\section{Al-Naggar \& Bobryshev}

Yawar A, Shah SS (2003). Faculty and students survey: methods of imparting knowledge suitable for undergraduate medical students. Pak J Med Res 42, 116-119. 